\title{
Impact of Outbound Logistics in Purchase Decision of Small Electronic Home Appliance Traders in Chittagong
}

Mohammad Naveed Ahmed, Institute of Business Administration (IBA), University of Dhaka, Dhaka, Bangladesh \& Hasib Electronics, Miyako Appliances Bangladesh, Dhaka, Bangladesh

\begin{abstract}
Outbound logistics focuses on the distribution to the point of sales, such as - collection, storage, and distribution systems etc. Marketers must understand - what the customer wants in terms of logistics and how it can create value to the customers? Based on this scenario, this study focuses on the fact that lack of understanding about the elements of outbound logistics is leading to lack of identifying it as value creation tool to impact the purchase decision in home appliances industry. In total around 490 home appliance traders is selected based on convenience from Chittagong city and interviewed based on a questionnaire in May 2016. Factor Analysis is used to identify the most relevant factors from 14 variables and then a regression analysis is used to show how each of those factors related to outbound logistics in small home appliance sector is impacting the purchase decision. The outcome is the trader's purchase decision equation which a marketer can use to identify the elements of outbound logistics where he can focus more to strengthen his logistics channel.
\end{abstract}

\section{KEYWORDS}

Factor Analysis, Outbound Logistics, Purchase Decision, Regression Analysis, Small Home Appliance, Value Chain

\section{INTRODUCTION}

Based on the report published by Euromonitor International (June, 2014), the consumer electronics market of Bangladesh experienced a current value CAGR of 14\% over 2009-2013 to reach USD 1.9 billion in the later year. A growing middle class, increasing consumer sophistication, and introduction of new products contributed to the growing sales of consumer electronics. As the usages of electronic appliances are growing in Bangladesh, local brands are becoming popular in the Small Home Appliance industry of Bangladesh, and as a result number of small appliance traders is also increasing. Based on industry experience, most of these traders are buying these appliance goods from different places in Bangladesh and then transport them to their facility or shop. Many arrange their own transport, some outsource the logistics support and others take the support from the appliance marketer themselves. Outbound Logistics outsourcing has a significant effect on how firms deliver products to their customers. Indeed, many firms do not own or manage the transportation and warehousing resources used for outbound shipments from their facilities. This research investigates how the outbound logistics is impacting the purchase decision of the small appliance traders in Chittagong City. 


\section{Framework}

The framework is shown in Figure 1.

\section{LITERATURE REVIEW}

It was in 1985 that the term "Value Chain" was coined by Michael Porter (Porter 1998) and all its subsidiary headings. For this research, the researcher will look at some of the literature surrounding the outbound logistics, primary activity of Porter's value Chain model and then it will discuss how consumer's purchase intention evolve. Using both dimensions of the literature, i.e. outbound logistics drivers and purchase intention, the researcher will check how both dimensions can be linked.

\section{PURCHASE INTENTION}

Consumers' buying decision is very complex. Keller (2001) mentioned usually consumers' behavior, perception and their attitude creates the purchasing intention. And in purchase behavior, intention is an important key point for consumers during taking into consideration and evaluating certain product. Ghosh (1990) stated that purchase intention is one of the key elements in purchasing process. Intention drives the consumers when they decide to purchase the product in certain store. However, purchase intention may be changed due to the influence of price, quality observation and value perception (Zeithaml, 1988 and Grewal et al, 1998). In addition, consumers will be provoked by internal impulse and external environment during purchasing process. In general, customers behavior will be altered or driven by the physiological drive that stimulates their action which bring them to the store to fulfill their need (Kim and Jin, 2001). The literature of purchase intention can be summarized by the diagram in Figure 2.

\section{OUTBOUND LOGISTICS DEFINITION}

Based on Investopedia, logistics is the general management of how resources are acquired, stored and transported to their final destination from the point of origin in order to meet customers' requirements. Johnson and Wood's definition (cited in Tilanus, 1997) mentioned logistics describes the entire

Figure 1. Framework

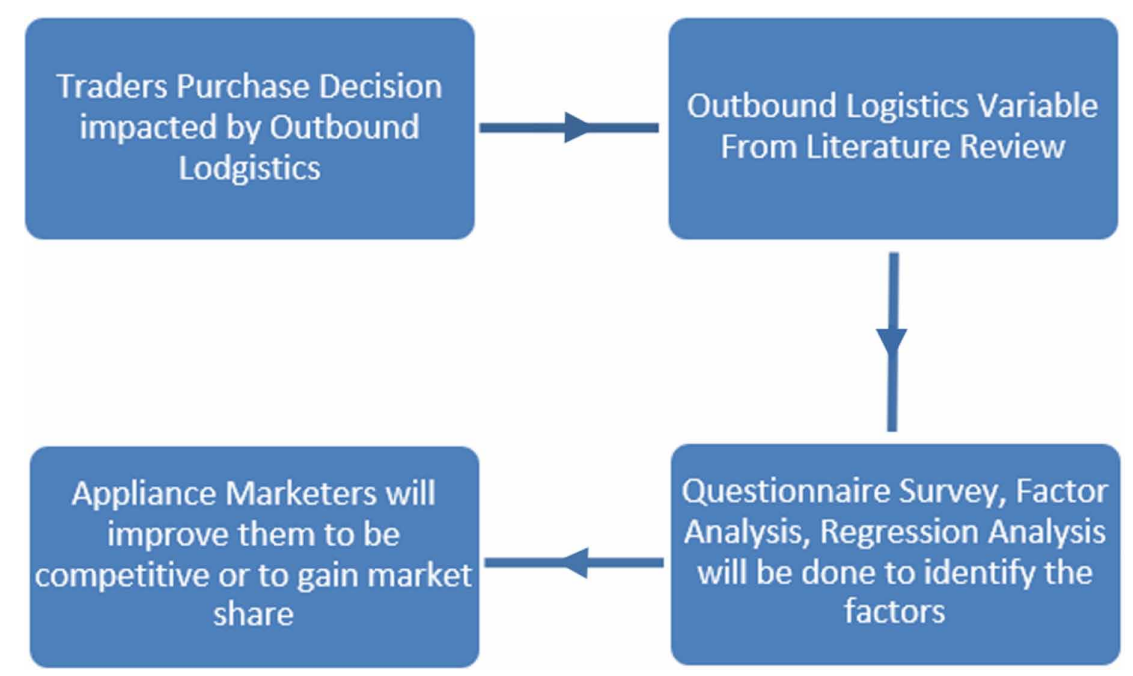




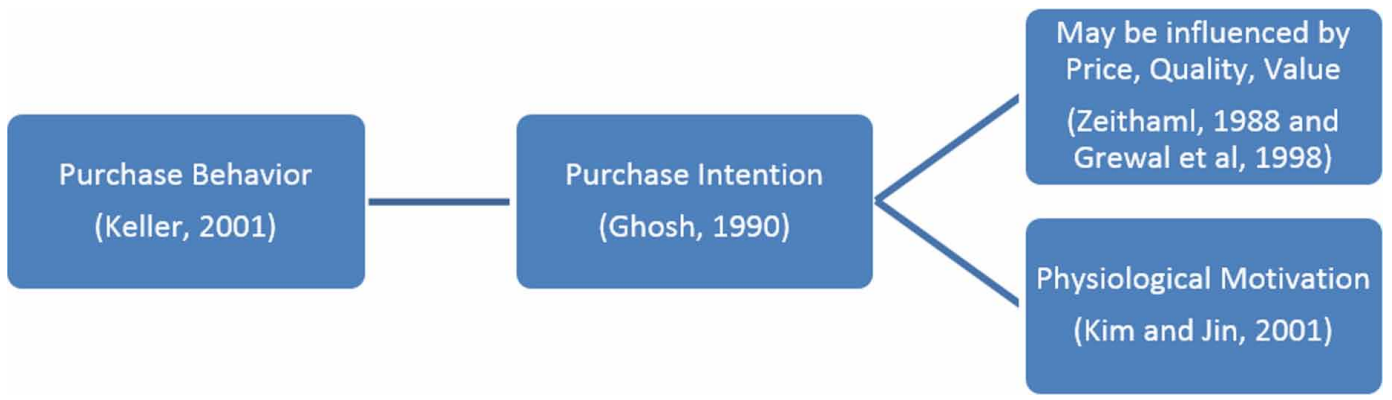

process of materials and products moving into, through, and out of firm. Inbound logistics covers the movement of material received from suppliers. Outbound logistics refers to the movement of goods outward from the end of the assembly line or from the warehouse to the customer. Recent development of logistics definitions argues that logistics is the process of anticipating customer needs and wants and optimizing the goods or service producing network to fulfill customer requests in a timely way (Tilanus, 1997). Combining all the literature, the researcher can argue that outbound logistics is a customer-oriented operation management.

\section{FACTORS IN OUTBOUND LOGISTICS}

The efficiency and effectiveness of the outbound logistics operation has a considerable influence not only on the business performance of the marketer but also on the customer's perception of the quality of the products and services provided by the marketer. The uncertainty of the flows of finished goods to the customer may create dissatisfaction to the firm's customer base. Accordingly, logistics is strategically important in achieving competitive advantage (Bowersox et al., 2010).

Logistics services comprises of two things - physical activities and non-physical activities. Physical activities refers to the activities like transport, storage etc. and non-physical activities include supply chain design, selection of contractors, freight negotiations etc. Most activities of logistics services are considered as bi-direction movement. Tracking and tracing is also an important element of logistics. It provides essential data in each step of the interaction among logistics services and the target destinations. Infrastructure comprises human resources, financial resources, packaging materials, warehouses, transport and communications.

The role of logistics system or method is more complex than carrying goods for the proprietors. Its complexity can only be confirmed by high quality management. With wellhandled transport system, goods could be sent to the right place at right time in order to satisfy customers' demands. It brings efficacy, and also it builds a bridge between producers and consumers. Therefore, transportation or logistics method is the base of efficiency and economy in business logistics and expands other functions of logistics system (Tseng et al., 2005). In addition, a good transport system performing in logistics activities brings benefits not only to service quality but also to company's competitiveness.

Typically, firms or businesses outsource a range of activities in order to be competitive. Reducing costs (Aimi, 2007; Jiang et al., 2006; Lau \& Zhang, 2006) is an important issue to outsource activities. Other reasons to outsource logistics related activities are to improve product quality (Bardhan et al., 2006), gain flexibility in decision making (Lau \& Zhang, 2006), develop market coverage (SkjoettLarsen, 2002), or to gain additional capacity (Linder, 2004; Mason et al., 2002). Elliott (2006, p. 22) argued that in most cases the objective of outsourcing is a targeted $20 \%$ cost reduction. Most of the 
research shows how outsourcing the outbound logistics is successful, but there is still a gap of how the factors associated with the logistics are impacting the purchase decision.

Customer service in logistics is the process of providing goods, information and services to customers in order to create satisfaction in cost-effective manner (Sadler 2007). Specifically, it talks about how the logistics provider handles the queries on "creation of time" and "place utility" (Christopher 2011). Products will not have value unless they have positioned to the right place when it is needed (Christopher 2011). But the required service elements should be developed by customers themselves (Christopher 2011). Shobha and Subramanya (2016) argued that strategically routing has helped us in identifying the right routes to be chosen in order to reduce the distance traveled and hence logistics cost.

Takele (2014) suggests outbound logistics provokes the customer's choice mainly in 3 aspects: availability, reliability, and flexibility. Lou Cortese (2003) mentioned all the logistics service provider's goal is to deliver the goods in damage free condition. Many providers offer insured service and confirm the security. Anderson, Britt, and Favre (1997) mentioned one of the major principle in supply chain management is strategically reducing the total cost of owning materials and services and developing a supply chain-wide technology strategy that supports multiple levels of decision making and gives a clear view of the flow of products, services, and information. Manikas and Ieromonachou (2016) suggested that logistics providers are aligned with customers choice and focuses on service quality priorities.

Based on this scenario in Table 1, this research primarily focuses on the fact that lack of understanding about the elements of outbound logistics is leading to lack of identifying it as a value creation tool to impact the consumer purchase decision in the small electronic home appliances industry of Bangladesh.

Table 1. Variables formation

\begin{tabular}{|c|c|c|c|c|c|}
\hline Indicators & \multicolumn{5}{|c|}{ Authors } \\
\hline Distance & \multicolumn{5}{|c|}{ Skjoett-Larsen (2002) } \\
\hline Cost & $\begin{array}{l}\text { Aimi } \\
(2007)\end{array}$ & $\begin{array}{l}\text { Elliott } \\
(2006, \mathrm{p} \text {. } \\
22)\end{array}$ & $\begin{array}{l}\text { Jiang, Frazier, \& Prater, } \\
2006\end{array}$ & Lau \& Zhang, 2006 & $\begin{array}{l}\text { Anderson et al } \\
\text { (1997) }\end{array}$ \\
\hline Duration & \multicolumn{5}{|c|}{ Christopher (2011) } \\
\hline Quick & \multicolumn{5}{|c|}{ Christopher (2011) } \\
\hline Security & \multicolumn{5}{|c|}{ Lou Cortese (2003) } \\
\hline Insurance & \multicolumn{5}{|c|}{ Lou Cortese (2003) } \\
\hline Reputation & \multicolumn{5}{|c|}{ Takele (2014) } \\
\hline Damage & \multicolumn{5}{|c|}{ Lou Cortese (2003) } \\
\hline Responsive & $\begin{array}{l}\text { Sadler } \\
(2007)\end{array}$ & $\begin{array}{l}\text { Tilanus, } \\
\text { (1997) }\end{array}$ & Christopher (2011) & \multicolumn{2}{|l|}{ Anderson et al. (1997) } \\
\hline Logistics means & \multicolumn{5}{|c|}{ Tseng et al. (2005) } \\
\hline On time & \multicolumn{2}{|c|}{ Christopher (2011) } & \multicolumn{3}{|l|}{ Anderson et al. (1997) } \\
\hline Inventory & \multicolumn{2}{|c|}{ Takele (2014) } & Christopher (2011) & \multicolumn{2}{|l|}{ Anderson et al. (1997) } \\
\hline Product Mix & \multicolumn{2}{|c|}{ Takele (2014) } & \multicolumn{3}{|l|}{ Anderson et al. (1997) } \\
\hline Support & \multicolumn{5}{|c|}{ Bowersox, Closs, \& Cooper (2010) } \\
\hline
\end{tabular}




\section{OBJECTIVES OF THE STUDY}

The aim of the research is to increase the current understanding of the factors that influence the small appliance traders purchase decision. The prime objectives of the study are as follows:

1. To identify the outbound logistics factors impacting the purchase decision of the small appliance traders in Chittagong city;

2. To evaluate the contribution of each factor on overall purchase decision of the small appliance traders in Chittagong city;

3. To suggest some measures of the outbound logistics factors impacting the purchase decision of the traders to improve the appliance marketers task performance in Chittagong city.

\section{RESEARCH METHODOLOGY}

Literature review has been done to identify the 14 outbound logistics related variables impacting the purchase decision of the small appliance related traders and then quantitative research methodology is used to fulfill the objectives of the research.

\section{SAMPLING AND DATA COLLECTION}

A survey was conducted on 490 small appliance traders of Chittagong city based on a questionnaire. The frame of respondents of the research was comprised of managers or owners of the small appliance shops of Chittagong city. Chittagong city was selected due to researcher's convenience, however the choice was also supported by several issues like - it is the oldest sea port city, appliance traders' density in Chittagong and historically Chittagong was considered as the main business area. 490 small appliance traders were selected by following random sampling method. The researcher visited the major appliance markets in Chittagong city and tried to get responses from the traders.

\section{QUESTIONNAIRE DESIGN}

Based on the literature review, 14 variables related to outbound logistics were identified which may impact the purchase decision. A structured, close ended questionnaire using 5-point Likert-type scale with end points ranging from strongly agree (5) to strongly disagree (1) was developed for the research to judge those 14 variables. The questionnaire also included necessary trading type related questions. Initially, a draft questionnaire was prepared based on secondary research and extensive brainstorming. The questionnaire was verified in a validation meeting consisting of professionals from the small appliance sector.

\section{DATA ANALYSIS}

Three types of analysis were carried out on this study:

1. Descriptive Analysis to explain the respondent Characteristics;

2. Factor analysis to group the response into the hypothesized quality attributes;

3. Regression analysis to find out if and to what extend the quality attributes impact the purchase decision of the small appliance traders. 


\section{FINDINGS}

The survey was done in Chittagong city on randomly selected 490 traders, which consisted of $52 \%$ retailers, $18.8 \%$ wholesaler, $6.1 \%$ suppliers, $19.6 \%$ distributors and $3.5 \%$ departmental stores. Here retailers are defined by the regular appliance traders who are visible in all general markets of Chittagong. Wholesalers are the one who do trading on bulk basis and are generally present in wholesale markets of Chittagong city like Riazuddin Bazar, New Market, Chalk Bazar area etc. Suppliers are defined by those entities that sources goods from wholesalers or distributors for other agencies or organizations based on the requirement of those agencies. Distributors are those sellers who are active in both retail and wholesale activities but under the umbrella of a brand or brands. Departmental stores are those traders who are not really appliance product centric but appliance is on their shelves along with other goods. Agora, Swapno, PQS - these stores are considered as departmental stores for this research.

As seen in Figures 3 through 6, 42\% of the traders trade single branded electronics appliance item and 57\% deals with different branded items. Around $66 \%$ of the traders arrange the outbound logistics by themselves based on their convenience which means their purchase decision also depends on the arrangement or availability of the outbound logistic support and while choosing the outbound logistics, $61 \%$ of the traders informed that, they consider the cost factors than the duration of the transportation.

Based on the literature review, 14 variables related to outbound logistics were identified which may impact the purchase decision. Questionnaire was designed to do factor analysis for those 14 variables on a 5 point likert scale to identify the most relevant factors related to outbound logistics which may impact the purchase decision of the trader in small home appliance industry (see Table 2). Cronbach's Alpha (0.552) confirms the reliability of the 14 variables data, which refers poor but acceptable data, based on George and Mallery (2003). KMO value is 0.678 which is higher

Figure 3. Distribution of traders

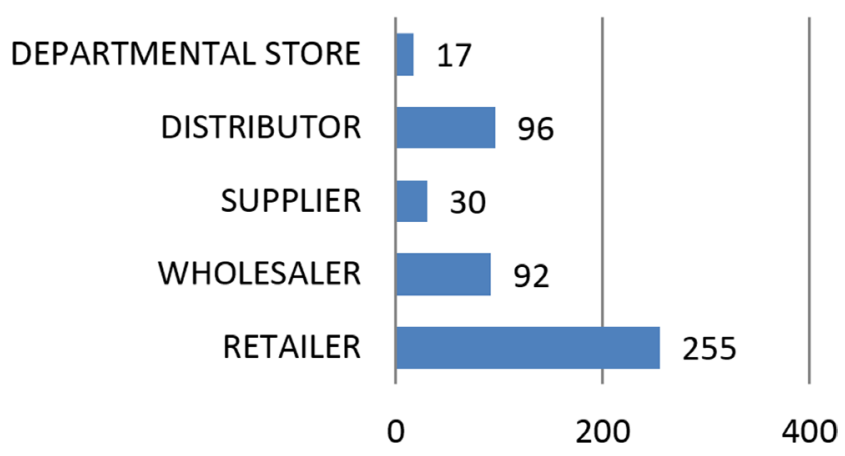

Figure 4. Small appliance traders product line

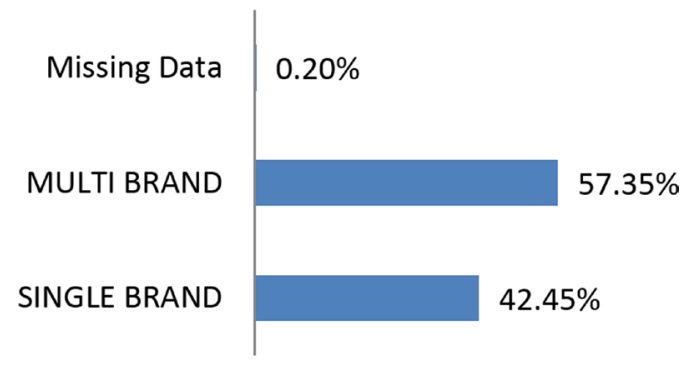


Figure 5. Distribution of arrangement of outbond logistics

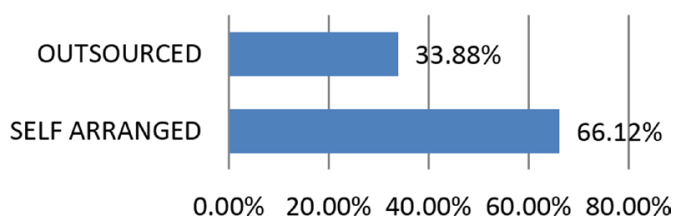

Figure 6. What most traders care more on outbound logistic

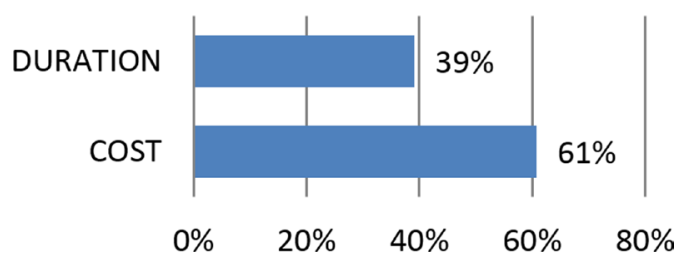

Table 2. Factor analysis

\begin{tabular}{|c|c|c|c|c|c|c|c|}
\hline \multirow{3}{*}{ Identified Factors } & \multicolumn{7}{|c|}{ Rotated Component Matrix ${ }^{a}$} \\
\hline & \multirow{2}{*}{ Variables } & \multicolumn{6}{|c|}{ Component } \\
\hline & & 1 & 2 & 3 & 4 & 5 & 6 \\
\hline \multirow{3}{*}{ Security of the outbound logistics } & Security & .755 & -.003 & .053 & -.049 & .107 & -.073 \\
\hline & Insurance & .722 & .018 & .122 & .029 & -.171 & .069 \\
\hline & Reputation & .597 & .068 & .160 & .412 & .110 & .057 \\
\hline \multirow{3}{*}{$\begin{array}{l}\text { Responsiveness of the logistics } \\
\text { provider }\end{array}$} & Responsive & -.007 & .711 & .125 & .120 & -.005 & -.033 \\
\hline & Distance & .196 & -.600 & -.039 & .389 & .140 & .115 \\
\hline & Damage & .297 & .517 & -.051 & .003 & .248 & .133 \\
\hline \multirow{3}{*}{ Inventory availability of the goods } & Quick & .265 & -.119 & .683 & -.022 & .041 & .055 \\
\hline & Inventory & -.138 & .137 & 620 & .240 & -.268 & .025 \\
\hline & Ontime & .228 & .219 & .569 & .099 & .188 & .038 \\
\hline \multirow[b]{2}{*}{ Methods of logistics } & Means of logistics & .000 & -.042 & .197 & .781 & .082 & -.010 \\
\hline & $\begin{array}{l}\text { Marketer's support on } \\
\text { logistics }\end{array}$ & .219 & .386 & -.386 & .461 & -.255 & -.007 \\
\hline Cost of logistics & Cost & .011 & .010 & .023 & .066 & .822 & .007 \\
\hline \multirow{2}{*}{ Duration of logistics } & Duration & .121 & -.173 & .069 & -.050 & -.208 & .791 \\
\hline & Product mix & -.118 & .188 & .036 & .081 & .343 & .676 \\
\hline
\end{tabular}

Extraction Method: Principal Component Analysis. Rotation Method: Varimax with Kaiser Normalization. ${ }^{a}$ Rotation converged in 7 iterations.

than 0.5 which shows the validity or adequacy of the sample. After running factor analysis, 6 factors were identified.

From the output in Table 2, it can be seen that security, insurance and reputation can be grouped under security factor of the logistics service provider which may impact the purchase decision of the trader from their sources. Other identified factors are responsiveness of the logistics support provider, inventory availability of the marketer or manufacturer, methods of logistics from the source to the trader, the cost of logistics and the duration from the source to the trader. 
Regression analysis is done based on these six factors to see how they impact the purchase decision of the trader (see Table 3). The regression model used was:

Impact on the Purchase Decision of the Trader $=3.196+0.505$ Methods of Logistics +.205 Security of the Outbound Logistics +.175 Responsiveness of the Logistics Provider +.109 Cost of Logistics + Error

Here, it is observed that adjusted- $\mathrm{R}^{2}$ is 0.181 which means the model may not be a good fit around the mean. However, it can be justified by the fact that all the traders are not from the same scale and future research can done based on classifying different types of traders (traders with big turnover, traders with small turnover etc.) so that a good fit model can be defined. But traders purchase decision which is related to human psychology, it is simply harder to define a good fit model.

From the regression model, it can be observed that inventory availability and the duration factor are excluded from the model as they are not significant. It can be justified as may be a reasonable time or duration is needed by any logistics company and they are similar for all the logistics or supporting companies; therefore do not have much impact on the purchase decision of the traders. Basically from the purchase decision model, it can be seen that an appliance marketer can focus more on partnering with logistics service provider who can offer secured service, and responsive in customer requirement handling. Moreover this service also need be cost efficient. Logistic means also plays an important role in the purchase decision making of the trader, as traders prefer to buy goods from the marketer based on their convenience. Traders often tend to buy goods from the marketers who are in the same city. However, sometimes this logistics means or methods are uncontrollable factor for the trader as roads development, infrastructure issues need to address to different authorities. Based on the informal discussion with the traders during the survey, it was understood that the Chittagong city traders prefer to buy goods from the appliance marketers in Dhaka if the price is better than other city. Some traders buy goods from the marketers of Chittagong or Khulna area if the product price along with the logistics price from that area is favorable than Chittagong city.

From the model, it can be seen that cost impacts the least among these 4 factors. It can be justified based on the scenario that, most of the transport companies offer similar types of rates based on their service. For example, cost for a carton of rice cooker transportation from Chittagong to Dhaka by different logistics service providers in Chittagong are shown in Table 4.

Table 3. Regression results

\begin{tabular}{|l|l|l|l|}
\hline \multicolumn{1}{|c|}{ Variable } & \multicolumn{1}{c|}{ Coefficient } & \multicolumn{1}{c|}{ t-Statistic } & \multicolumn{1}{c|}{ Prob. } \\
\hline Intercept & 3.196 & 57.967 & .000 \\
\hline SECURITY & .205 & 3.715 & .000 \\
\hline RESPONSIVE & .175 & 3.175 & .002 \\
\hline INVENTORY & -.040 & -.733 & .464 \\
\hline LOGISTICS_MEANS & .505 & 9.144 & .000 \\
\hline COST & .109 & 1.975 & .049 \\
\hline DURATION & .079 & 1.430 & .153 \\
\hline & & & \\
\hline R-Squared $(\%)$ & .191 & & \\
\hline Adjusted R-Squared $(\%)$ & .181 & & \\
\hline Model F value & 18.998 & & \\
\hline
\end{tabular}


Table 4. Cost for a carton of rice cooker transportation from Chittagong to Dhaka by different logistics service providers

\begin{tabular}{|l|l|l|l|l|l|l|}
\hline \multicolumn{1}{|c|}{ Korotowa } & \multicolumn{1}{c|}{ Sundarban } & \multicolumn{1}{c|}{ Continental } & \multicolumn{1}{c|}{ Dipika } & \multicolumn{1}{c|}{ Agomoni } & \multicolumn{1}{c|}{ Shomrat } & \multicolumn{1}{c|}{ Average } \\
\hline TK. 95 & TK. 120 & TK. 120 & TK. 80 & TK. 75 & TK. 80 & TK. 95 \\
(USD 1.19) & (USD 1.50) & (USD 1.50) & (USD 1.00) & (USD 0.94) & (USD 1.00) & (USD 1.19) \\
\hline
\end{tabular}

Source: Logistics Service Provider's Information

From Table 4, it can be seen that a standard rice cooker carton from Chittagong to Dhaka is similar, but it makes a big difference, when the trader buy goods in bulk quantity. So, it can be understood that in the equation, cost factor is having minimal role as it plays an important role the trader buys in bulk and it does not when the trader buys few pieces.

\section{CONCLUSION}

The primary objective of this research was to identify the elements where an appliance marketer can focus to create more value to their customers in terms of logistics. And while indentifying the elements, this paper also attempted to create a model on how logistics factors impact purchase behavior of the traders. Based on the model, the following four recommendations can be made to marketers in the small appliance industry. First, it is better to provide support on outbound logistics related service to gain better market access, and it can be done either by owning them or by having partnership with good logistics company. Second, security of the transportation and responsiveness of the logistics company should be the key element while partnering with the logistics company. Third, cost issues should be monitored as it also impacts the purchase behavior. However, marketers must focus more on providing logistics related customer services, for example, query handling, security, insurance, and safety. Fourth, the logistics means places an important role on the purchase decision of the traders, which is uncontrollable factor for the traders; however they can improve the situation by doing strategic planning on their warehouse / inventory location.

\section{Limitation}

This research sample is only from Chittagong city; hence the purchase decision impact model might not be same for other cities in Bangladesh or in other nations, however it is an image of the traders mind on how they make the decision. Further research can be done on other cities and by comparing different types of customers, like small traders, wholesalers, retailers or the end users. 


\section{REFERENCES}

Aimi, G. (2007). Logistics outsourcing: What it takes to succeed. Supply Chain Management Review, 11(8), 13.

Anderson, D. L., Britt, F. F., \& Favre, D. J. (1997), 7 Principles of Supply Chain Management, Ten Classics from Supply Chain Management Review, Online: http://www.scmr.com/images/01.SevenPrinciples_pdf

Ballou, R. (1997). Business Logistics Importance and Some Research Opportunities. Gestão \& Produção, 4(2), $117-129$.

Bardhan, I., Whitaker, J., \& Mithas, S. (2006). Information technology, production process outsourcing, and manufacturing plant performance. Journal of Management Information Systems, 23(2), 13-40. doi:10.2753/ MIS0742-1222230202

Bowersox, D. J., Closs, D. J., \& Cooper, M. B. (2010). Supply Chain Logistics Management (3rd edition ed.). Boston, MA: McGraw-Hill.

Christopher, M. (2011). Logistics and Supply Chain Management. Harlow, NY: Pearson.

Cortese, L. (2003), Reducing the Risk of Damage, Loss and Claims. Retrieved 28 July 2016 from http://www. inboundlogistics.com/cms/article/reducing-the-risk-of-damage-loss-and-claims/

Elliott, G. C. (2006). International outsourcing: Values vs. economics. Quality Progress, 39(8), 20-25.

Ghosh, A. (1990). Retail management. Chicago, IL: Drydden press.

Grewal, D., Krishnan, B., Baker, J., \& Borin, N. (1998). The effect of store name, brand name, and price discount on consumers' evaluations and purchase intention. Journal of Retailing, 74(3), 331-352. doi:10.1016/ S0022-4359(99)80099-2

Jiang, B., Frazier, G. V., \& Prater, E. L. (2006). Outsourcing effects on firms' operational performance: An empirical study. International Journal of Operations \& Production Management, 26(12), 1280-1300. doi:10.1108/01443570610710551

Keller, K. L. (2001). Building customer-based brand equity. Marketing Management., 10(2), 14-19.

Kim, J. O., \& Jin, B. H. (2001). Korean consumers' patronage of discount stores: Domestic vs. multinational discount stored shoppers' profile. Journal of Consumer Marketing, 18(3), 236-255. doi:10.1108/07363760110393092

Lau, K. H., \& Zhang, J. (2006). Drivers and obstacles of outsourcing practices in China. International Journal of Physical Distribution \& Logistics Management, 36(10), 776-792. doi:10.1108/09600030610714599

Linder, J. C. (2004). Transformational Outsourcing. MIT Sloan Management Review, 45(2), 52-58.

Manikas, I., \& Ieromonachou, P. (2016). Do the service priorities of companies outsourcing to 3PL providers vary by industry? International Journal of Applied Logistics, 6(1), 64-96. doi:10.4018/ IJAL.2016010105

Mason, S. J., Cole, M. H., Ulrey, B. T., \& Yan, L. (2002). Improving electronics manufacturing supply chain agility through outsourcing. International Journal of Physical Distribution \& Logistics Management, 32(7), 610-620. doi:10.1108/09600030210442612

Sadler, L. (2007). Logistics and Supply Chain Integration. London, UK: Sage.

Shobha, N.S., \& Subramanya, K.N. (2016), Outbound logistics modeling using shortest routing algorithm in a lean enterprise: A case study. The IUP Journal of Supply Chain Management, December 2016

Skjoett-Larsen, T. (2002). Third Party Logistics - From an inter-organizational point of view. International Journal of Physical Distribution \& Logistics Management, 30(2), 112-127. doi:10.1108/09600030010318838

Takele, T. B. (2014). Customer satisfaction measurement conceptual model for outbound logistics. Research Journal of Social Science and Management, 4(7), 178-183. 
Tilanus, B. (1997). Information Systems in Logistics and Transportation. Tarrytown, NY: Pergamon.

Tseng, Y. Y., Yue, W. L., \& Taylor, M. A. P. (2005). The role of transportation in logistics chain. Proceedings of the Eastern Asia Society for Transportation Studies, 5, 1657-1672.

Zeithaml, V. A. (1988). Consumer perceptions of price, quality and value: A means-end model and synthesis of evidence. Journal of Marketing, 52(3), 48-62. doi:10.2307/1251446 